\title{
23. COMPARISON OF GLORIA SIDESCAN SONAR AND CORE-DERIVED STRUCTURAL DATA FROM SITE 841 (TONGA TRENCH) ${ }^{1}$
}

\author{
C.J. MacLeod ${ }^{2}$ and A.M. Lothian ${ }^{3}$
}

\begin{abstract}
The area surrounding Ocean Drilling Program Site 841, on the inner (landward) slope of the Tonga Trench, was also surveyed using the GLORIA long-range sidescan sonar system on Charles Darwin Cruises 33 and 33B. The GLORIA sonographs show a variety of acoustic facies on the inner trench slope: even-textured, low-backscattering areas correspond to mid-slope terrace basins; irregular, highly backscattered areas are interpreted as basement outcrops; and mottled areas of seafloor probably delineate mass-wasted slope deposits. Much of the inner trench slope is traversed by near-trench-parallel lineaments on a variety of scales. The larger lineaments often correspond to bathymetric discontinuities and almost certainly represent fault scarps; however, many short, discontinuous, kilometer-scale linear features within the areas of mottled seafloor parallel the ship's track precisely and it is possible to demonstrate that many are artefacts on the sonographs. Unfortunately, the ship's track itself was parallel to the trend of the trench for most of the survey, and beam spreading/diffraction effects have elongated point-source features, smearing out many (slightly oblique) linear features parallel to the ship's track. The distribution of lineaments that results is therefore very strongly track-parallel and does not reflect the true variability in lineament distribution.

Oriented subsurface structural data have been obtained from Site 841, derived from both core and downhole measurements, and are in this paper compared with surface structural information inferred from lineament analysis of the GLORIA sonographs. The downhole and sonar data are entirely independent of each other, and offer a rare opportunity to assess the strengths and weaknesses of the two different methods of structural interpretation of an area of seafloor.
\end{abstract}

\section{INTRODUCTION}

The 1988 Charles Darwin Cruises 33 and 33B obtained GLORIA sidescan sonar images of the axial part of the north-northeast-trending Tonga Trench between $22^{\circ}$ and $27^{\circ} 30^{\prime} \mathrm{S}$. Coverage included that portion of the inner trench wall (outer forearc) that was later to be drilled on Ocean Drilling Program (ODP) Leg 135 (Site 841) in February 1991. The GLORIA records of this area display many linear, highbackscattering features, which are thought to be fault scarps. Analysis of the nature and orientation of these lineaments has allowed us to attempt an interpretation of the structure of this part of the outer forearc.

An assessment of the structure of the Tonga forearc at Site 841 has also been made from an examination of the recovered core in conjunction with Formation MicroScanner (FMS) electrical images of the borehole wall (MacLeod, this volume). Structural data acquired from the FMS, either directly or from core reoriented by comparison with the images, are entirely independent of the interpretations of structure that are based upon GLORIA lineament analysis. The aim of this paper is to compare and contrast the Site 841 core/FMS subsurface fault data with the interpreted GLORIA images, and discuss the possible effects of processing and other artefacts that are thought to bias conventional analyses of sidescan sonar data.

\section{The Tonga Trench and Louisville Ridge}

The Tonga Trench is the site of subduction of the Pacific Plate beneath the Indo-Australian Plate. A zone of seismicity dipping westward beneath the trench defines the position of the subducting Pacific slab to a depth of more than $700 \mathrm{~km}$ (Isacks and Barazangi, 1977; Fischer et al., 1991). Relative plate convergence is estimated to be between 15 and $23 \mathrm{~cm} / \mathrm{yr}$ (Lonsdale, 1986; Pelletier and Louat, 1989)

\footnotetext{
${ }^{1}$ Hawkins, J., Parson, L., Allan, J., et al., 1994. Proc. ODP, Sci. Results, 135: College Station, TX (Ocean Drilling Program).

${ }^{2}$ Institute of Oceanographic Sciences, Brook Road, Wormley, Surrey GU8 5UB, United Kingdom.

${ }^{3}$ School of Earth Sciences, University of Birmingham, Edgbaston, Birmingham B15 2TT, United Kingdom.
}

and is orthogonal to the $020^{\circ}$ average trend of the trench. At a latitude of approximately $26^{\circ} \mathrm{S}$ a north-northwest-trending chain of guyots and seamounts is entering the trench and is being subducted (Fig. 1A). This, the Louisville Ridge, can be traced across much of the Pacific, parallels the Hawaiian-Emperor Seamount Chain (Clague and Jarrard, 1973), and is thought to be hotspot related (Lonsdale, 1988; Watts et al., 1988). Because of the obliquity between the trend of the Louisville Ridge and the convergence direction, the collision zone between the ridge and the trench is migrating southward along the trench at a rate of about $18 \mathrm{~cm} / \mathrm{yr}$ (Lonsdale, 1986). The forearc near the collision zone is unusually shallow, with the trench axis shoaling to a depth of less than $6000 \mathrm{~m}$ over a length of some $250 \mathrm{~km}$; to the north of the present collision zone the postcollisional inner trench slope is far steeper $\left(\geq 10^{\circ}\right.$ slope between 6000 and $\left.9000 \mathrm{~m}\right)$, and the trench axis deeper (10,866 m in the Horizon Deep Bight: Lonsdale, 1986), than in the Tonga/Kermadec Trench to the south of the intersection (mean slope $1^{\circ}-2^{\circ}$, depth $\sim 8000 \mathrm{~m}$ : Dupont and Herzer, 1985; Gnibidenko et al., 1985; Lonsdale, 1986; Ballance et al., 1989). The trench axis strikes north-south for $250 \mathrm{~km}$ to the north of the collision zone before, at approximately $23^{\circ} 30^{\prime} \mathrm{S}$, gradually bending back to reassume its regional $020^{\circ}$ to $030^{\circ}$ trend (Fig. 1A).

\section{Site 841}

Site 841 is located at latitude $23^{\circ} 20.7^{\prime} \mathrm{S}$, longitude $175^{\circ} 17.9^{\prime} \mathrm{W}$ on the outer slopes of the Tonga forearc, on a small north-south elongate topographic arch very close to the trench-slope break (Fig. 1A; Parson, Hawkins, Allan, et al., 1992). The regional trend of the trench and forearc changes from $000^{\circ}$ to $030^{\circ}$ at approximately this latitude. The site is approximately $40 \mathrm{~km}$ to the west of the axis of the Tonga Trench, directly upslope from the Horizon Deep Bight, and some 60 $\mathrm{km}$ east of the crest of the Tonga forearc platform. Three holes were drilled, in $4810 \mathrm{~m}$ of water, Hole 841B attaining a total depth of 834.2 $\mathrm{m}$ below seafloor (mbsf) (Parson, Hawkins, Allan, et al., 1992).

Detailed descriptions of the recovered cores from Site 841 are given in Parson, Hawkins, Allan, et al. (1992), and in this volume. In summary, about $600 \mathrm{~m}$ of middle Eocene to Holocene, predominantly volcaniclastic sedimentary strata were drilled before a low-potassium 
A

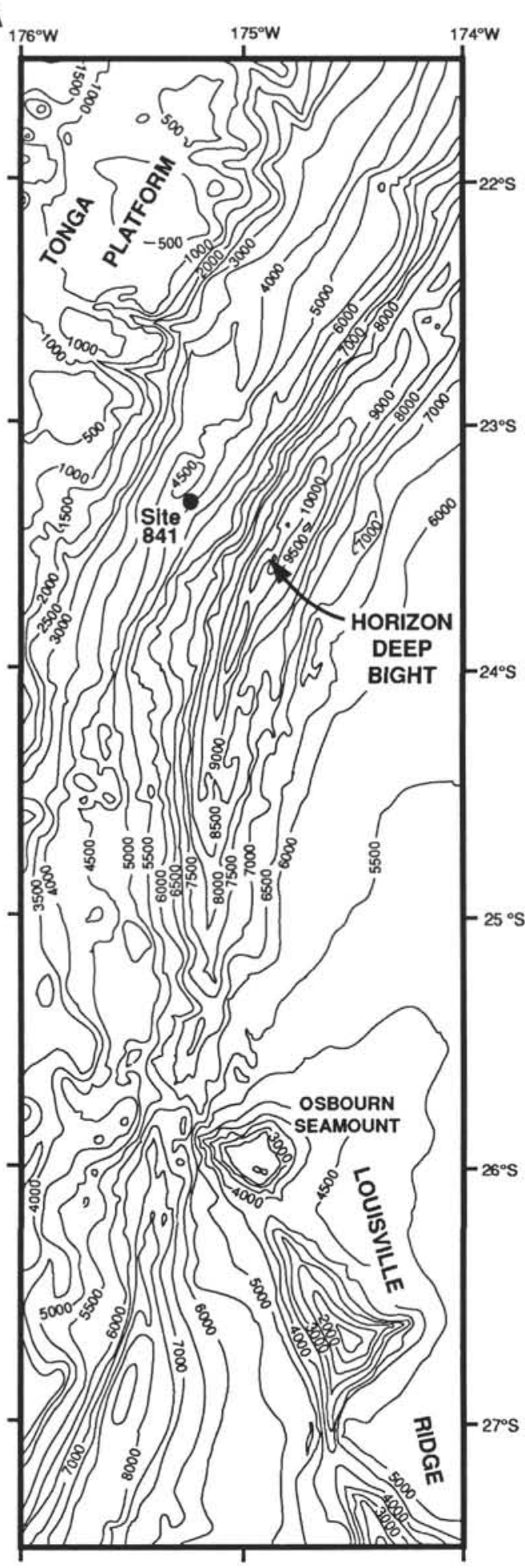

B

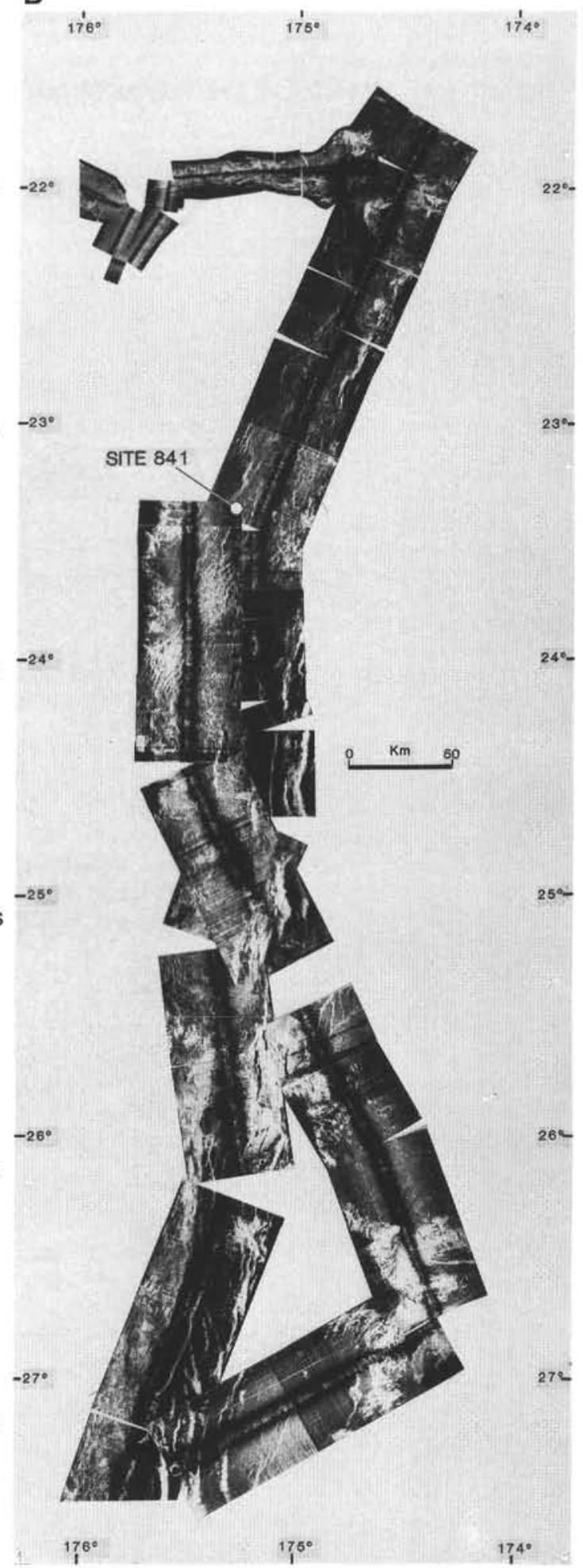

Figure 1. A. Bathymetric map of the Tonga Trench between $22^{\circ}$ and $27^{\circ} \mathrm{S}$. The Louisville Ridge seamount chain is in the process of being subducted; because it is oriented obliquely to the $290^{\circ}$ direction of plate convergence the zone of collision is sweeping southward down the trench axis at a rate of $\sim 18 \mathrm{~cm} / \mathrm{yr}$ (Lonsdale, 1986). In the wake of the zone of collision the forearc is indented, to form a $250-\mathrm{km}$-long, north-trending embayment characterized by extremely steep slopes and a much deeper trench axis (the Horizon Deep Bight). Bathymetric contours in meters. B. GLORIA mosaic of the same area of the Tonga Trench, from Charles Darwin Cruises 33 (Parson et al., 1989) and 33B (C.L. Jacobs, pers. comm., 1992). 
rhyolitic arc complex was encountered. Fauna in the lowermost (Eocene) sediments indicate deposition in shallow water, photic zone conditions, and welding of rhyolitic tuffs in the igneous basement suggests eruption in a subaerial environment; together, these require the site to have subsided at least $5.4 \mathrm{~km}$ since the middle-late Eocene.

\section{STRUCTURE OF THE TONGA TRENCH}

\section{Previous Work}

Studies of the Tonga Trench and outer Tonga forearc before Leg 135 were based principally upon the results of dredging (Fisher and Engel, 1969; Bloomer and Fisher, 1987; Vallier et al., 1985), earthquake focal mechanism studies (e.g., Isacks et al., 1969; Isacks and Barazangi, 1977), seismic reflection profiling (Dupont, 1982; Dupont and Herzer, 1985; von Huene and Scholl, 1991; Parson, Hawkins, Allan, et al., 1992), and limited multibeam swath bathymetric surveying (Lonsdale, 1986; Pontoise et al., 1986). Limited site surveying before the ODP drilling included $3.5-$ and $10-\mathrm{kHz}$ profiling and the GLORIA surveys discussed here (Parson et al., 1989; C.L. Jacobs, pers. comm., 1992).

Most of the multichannel seismic studies have concentrated on the Tonga forearc platform (e.g., Herzer and Exon, 1985; Austin et al., 1989; Tappin et al., 1992), but data from the Tonga Trench were collected by the U.S. Geological Survey (USGS) in 1982 with the S.P. Lee. Some of these trench profiles are published in Scholl et al. (1985), Dupont and Herzer (1985), von Huene and Scholl (1991), and Parson, Hawkins, Allan et al. (1992). Site 841 is situated along S.P. Lee multichannel line 82-12. This profile, and several single-channel seismic lines collected on Charles Darwin Cruise 33 and ODP Leg 135 , show evidence for recent faulting in the form of discontinuous and/or offset reflectors, including the seabed reflector. That these recent faults are of extensional origin is suggested by the recovery of cores from Hole 841A showing small-scale normal faulting within 10 $\mathrm{m}$ of the mud line (Parson, Hawkins, Allan, et al., 1992; MacLeod, this volume), and by in situ stress measurements from Sites 840 and 841 that show the present-day extensional stress direction in the forearc to be approximately perpendicular to the north-northeast trend of the Tonga Ridge and Trench (MacLeod and Pratt, this volume).

The Tonga Trench is sediment-starved in comparison with most other subduction zones: basement outcrops are common on both the inner and outer trench walls and no accretionary prism is present (e.g., von Huene and Scholl, 1991). Dredging has shown that outcrops of plutonic rocks presumed to belong to the lower crust of the overriding plate are exposed on the inner wall of the trench (Fisher and Engel, 1969; Vallier et al., 1985; Bloomer and Fisher 1987). Gabbros have been recovered at depths greater than $7000 \mathrm{~m}$ below sea level, and serpentinized ultramafics of upper mantle origin below approximately $8500 \mathrm{~m}$ (Bloomer and Fisher, 1987). Exposure of these deep crustal and upper mantle lithologies has been taken as evidence for tectonic erosion of the forearc (Bloomer and Fisher, 1987).

Swath bathymetry and reflection seismic studies show that the downgoing plate is being deformed into horsts and graben, presumably in response to bending of the lithosphere as it enters the subduction zone (Pontoise et al., 1986; Lonsdale, 1986; Masson, 1991). Fault scarps in the downgoing plate have a relief of up to $1000 \mathrm{~m}$. Remarkably, traces of horsts and graben have been identified on the migrated USGS multichannel seismic lines to a depth of at least $7 \mathrm{~km}$ below seafloor and more than $25 \mathrm{~km}$ to the west of the trench axis (von Huene and Scholl, 1991). This suggests that the horst-and-graben relief of the downgoing slab initially survives subduction and that the graben must be filling with material derived from the overriding plate. Significant quantities of material may be removed from the front and the base of the forearc in this fashion (e.g., Hilde, 1983; Ballance et al., 1989; von Huene and Scholl, 1991).

\section{GLORIA Imagery}

GLORIA (Geological Long Range Inclined ASDIC) is a wellproven, large-scale reconnaissance swath mapping sonar tool (Somers et al., 1978; Laughton, 1981; Searle et al., 1990) that has been in use for more than two decades. The sonar vehicle is towed at a depth of approximately $40 \mathrm{~m}$ below sea level and transmits a $2.7^{\circ}$ wide, $6.7 / 6.3-\mathrm{kHz}$ acoustic signal to the port and starboard sides, respectively. At an average towing speed of $8 \mathrm{kt}$, the pulse repetition period of $30 \mathrm{~s}$ gives a maximum swath width of $45 \mathrm{~km}$. This results in an along-track resolution of approximately $120 \mathrm{~m}$ (at a speed of $8 \mathrm{kt}$, or $150 \mathrm{~m}$ at $10 \mathrm{kt}$ ) in the near range, increasing to $1200 \mathrm{~m}$ in the far range, compared with an across-track resolution of only $45 \mathrm{~m}$ (Searle et al., 1990). Ship's velocity and slant range corrections are applied on ship to produce monitor data for quality control, with the data being stored digitally for further processing post-cruise (including filtering, normalization, and digital mosaicking: Chavez, 1986; Searle et al., 1990; Johnson and Helferty, 1990). The processed sonograph image is a spatially correct graphical presentation of the interaction of the transmitted acoustic energy with the seabed. The strength of the return signal or backscatter is a complex function that depends principally upon (1) the acoustic impedance contrast of the target; (2) the angle of incidence of the acoustic beam (usually the slope of a feature); and (3) its microtopography or surface roughness. Further discussion of image processing and interpretation is given by Searle et al. (1990) and Johnson and Helferty (1990) and references therein.

The digital GLORIA records from Cruises CD33 and CD33B discussed in this paper were processed as above at the Institute of Oceanographic Sciences Deacon Laboratory using the VAX-based Mini Image Processing System (MIPS). In addition to the standard processing we also tested the deblurring algorithms of Mason et al. (1992), which are designed to improve along-track resolution at medium and far ranges. Unfortunately, however, application of the algorithms made little difference to the quality of the images, and no change at all to our lineament analyses (discussed below).

The GLORIA images of the Tonga Trench extend between latitudes $22^{\circ} \mathrm{S}$ and $27^{\circ} 30^{\prime} \mathrm{S}$. They cover the inner slope and, south of $\sim 24^{\circ} \mathrm{S}$, also include the trench axis, part of the outer slope, and two seamounts of the Louisville chain (Fig. 1B; Mayer et al., 1990). The sonographs show a complex pattern of acoustic features, the interpretation of which is far from straightforward. A contrast is immediately apparent between the inner and outer trench slopes, however: whereas the inner slope is typically characterized by small, discontinuous linear features (see below), on the outer slope fewer, but significantly larger, high backscattering lineaments are observed parallel to the trench axis (Fig. 1B). The major bright lineaments and their associated acoustic shadows on the outer slope correspond to fault scarps that delineate the horst and graben topography of the subducting Pacific Plate. They may be traced laterally for up to $50 \mathrm{~km}$, are spaced 1-10 $\mathrm{km}$ apart and have throws of 100-500 m, occasionally up to $1000 \mathrm{~m}$, close to the trench axis (Lonsdale, 1986; Pontoise et al., 1986; Masson, 1991). The seamounts of the Louisville chain appear on the GLORIA records as irregular features with extremely high backscatter, within areas of uniform and low backscatter on the outer trench slope. The high acoustic backscatter of the seamounts is thought to indicate rough "basement" outcrop, and the bright triangular areas that broaden away from their centers to represent scree aprons. Mayer et al. (1990) interpret the low backscatter regions as sediment ponds filling depressions around the seamounts.

GLORIA images of the inner trench slope cover the post-, syn-, and precollisional portions of the forearc from north to south, respectively. On the inner slope close to the collision zone, to the west of the Ozbourn Seamount, the topography is extremely rugged, and backscattering levels are high and relatively uniform. The high back- 
scatter may indicate extensive basement outcrop, substantial mass wasting, or a combination of the two. This portion of the inner trench slope resembles an incipient version of the bright backscattering "collision scars" described from the sites of seamount subduction in the inner slope of the Java Trench by Masson et al. (1990).

Elsewhere along the inner slope, in precollisional and postcollisional areas, the sonographs have a typical even to finely mottled texture, characterized by a high density of short $(0.5-7 \mathrm{~km})$, closely spaced ( $<1.5 \mathrm{~km}$ separation), discontinuous high-backscattering linear features (Fig. 2A), interspersed with a smaller number of longer, high-backscattering lineaments. Comparison of the sonographs with the bathymetry data (Figs. 1-2) shows that many of the longer lineaments coincide with scarps of the order of $100 \mathrm{~m}$ in height, the vast majority of which step down eastward toward the axis of the trench. Reference to multichannel seismic lines (USGS line 82-12) shows that some of the lineaments coincide with the high angle discontinuities in the seismic records that are interpreted as recent faults (Parson, Hawkins, Allan, et al., 1992; and see above). Together, these observations offer strong support that the larger lineaments on the inner slope indeed represent fault scarps.

The short, discontinuous, high density linear features that characterize large areas of the inner slope are most well developed below the trench-slope break. They apparently parallel the strike of the trench very closely, swinging from a north-south to north-northeast-southsouthwest orientation between $24^{\circ} 30^{\prime}$ and $23^{\circ} \mathrm{S}$, as the trend of the trench changes. However, the lineaments also parallel the ship's track, and their change in orientation coincides precisely with the change in ship's heading from $\sim 205^{\circ}$ to $180^{\circ}$. Moreover, at $24^{\circ} 30^{\prime} \mathrm{S}$, where the CD 33 and CD $33 \mathrm{~B}$ cruise sonographs overlap, but with vehicle tracks at an angle of $45^{\circ}$ to each other, the lineaments remain track- and not trench-parallel (Fig. 2A), and cut across the contours. Given this proven correlation between the trend of the shorter, discontinuous lineaments and the ship's track, we are forced to conclude that the acoustic backscatter is being biased in some way by an instrument or processing artefact. This is discussed in more detail below.

Two elliptical regions, each up to $15 \mathrm{~km}$ across, of uniformly high backscatter are distinguishable along the northern inner trench wall at $22^{\circ} \mathrm{S}, 174^{\circ} 30^{\prime} \mathrm{W}$, in the postcollisional zone (Fig. 1A). Mayer et al. (1990) tentatively interpret these as erosional aprons surrounding serpentinite diapirs. Several homogeneous, even-textured low backscattering areas up to $-300 \mathrm{~km}^{2}$ in area are visible upslope from the trench-slope break between $22^{\circ}$ and $24^{\circ} \mathrm{S}$ (Fig. 2A). These areas of low backscatter correspond to terraces, or interruptions in the slope of the forearc, at a depth of approximately $4000-4500 \mathrm{~m}$ (Fig. 2B), and are interpreted here as sediment-filled mid-slope terrace basins.

Figures $2 \mathrm{~A}$ and $2 \mathrm{~B}$, respectively, show GLORIA and bathymetric data from a $13,000-\mathrm{km}^{2}$ area in the vicinity of Site 841 . The drill site lies immediately downslope from one of the mid-slope terrace basins, and is separated from the basin by a large northeast-striking, southeast-facing, strongly backscattering lineament that probably marks a genuine fault scarp (Fig. 2A). Other trench-parallel lineaments lie in a broad indentation in the trench slope between this terrace basin and another basin $50 \mathrm{~km}$ to the north-northeast. Some $30-40 \mathrm{~km}$ to the southwest of Site 841 a broad area of low, even backscatter cut by a few brighter, sinuous lineaments straddles the vehicle track. This area also lies above the trench-slope break and may be another terrace basin. This basin is bounded to the west by the much steeper slopes of the edge of the Tonga platform, imaged on the extreme western edge of the GLORIA records to the south of $23^{\circ} 20^{\prime} \mathrm{S}$ (Fig. 2A). The platform itself is mostly at less than $1500 \mathrm{~m}$ water depth and is in acoustic shadow, but high backscattering lobes, building out from the edge of the platform, are visible. These are probably scree aprons.

Downslope from the drill site, the GLORIA records show an irregular, mottled, and blotchy pattern with predominantly moderatehigh backscattering and discontinuous lineaments parallel to both the trench and ship's track. This mottled acoustic signature is found on the steep slopes of the inner trench wall below the trench-slope break right down almost to the axis of the Horizon Deep Bight, and is also visible on the lower trench slopes across much of the postcollisional part of the inner wall. No clear disruption of the contours is associated with the mottled terrain, implying that the irregularities are on a scale finer than the $100-\mathrm{m}$ resolution of the bathymetric map. One exception is a particularly high-backscattering feature (with associated acoustic shadow) $\sim 4 \mathrm{~km}$ in diameter that lies about $15 \mathrm{~km}$ to the east-southeast of Site 841 (Fig. 2A), and which coincides with a 200 $m$ high edifice on the accompanying bathymetric chart (Fig. 2B). The $10-\mathrm{kHz}$ records indicate that the mottled terrain is more typically characterized by rounded antiformal structures with amplitudes from 30 to $100 \mathrm{~m}$. We think that the seafloor here is likely to be composed principally of irregular blocks and other debris ranging up to a few kilometers in size that have accumulated by slope failure and downslope transport, resulting in an essentially chaotic surface with few continuous features that might focus the backscatter into more coherent acoustic returns. The majority of the short, discontinuous, trackparallel lineaments observed here are likely to be artefacts caused by the beam spreading/data smearing inherent in sidescan sonar imaging. Most of the targets that give rise to the acoustic returns are, in effect, point-source diffractors that have been elongated parallel to the ship's track. In this we differ slightly from Mayer et al. (1990), who interpret the linear acoustic fabric in terms of superposed slumps that have failed on sinuous fronts up to $10 \mathrm{~km}$ long parallel to the trench axis. Tectonic deformation of the slumped material is likely, but may only be identified with any confidence if fault scarps thus formed are several kilometers in length. We also point out the similarity between the irregular fabric of the mottled terrain described here and the acoustic fabrics of some of the major landslide deposits recognized on GLORIA images from around the Hawaiian Islands (Kayen et al., 1990; C.L. Jacobs and J.B. Wilson, unpubl. data, 1992).

Between approximately $23^{\circ} 40^{\prime}$ and $24^{\circ} 20^{\prime} \mathrm{S}$, a different acoustic fabric is observed on the inner trench wall. This fabric forms a northnortheast-trending zone of significantly higher overall backscatter, $20-30 \mathrm{~km}$ wide and $60 \mathrm{~km}$ long, within which a large number of closely spaced lineaments $\sim 3-4 \mathrm{~km}$ apart are visible. This zone, which lies between approximately 5000 and $7500 \mathrm{~m}$ water depth, forms the steepest part of the inner wall at this latitude, with slopes averaging $\sim 10^{\circ}$ (Fig. 2B). The high backscattering fabric of this zone probably corresponds to bare basement rock outcrop. The lineaments within it are generally more continuous than those of the mottled lower slopes, and many of the lineaments are oblique to the ship's track; hence, it appears reasonable to interpret them as fault scarps. Most trend at approximately $030^{\circ}$, parallel to the contours, and are east-southeastfacing (i.e., stepping downward into the trench). Closer inspection, however, reveals some variability in the trend of the lineaments, which range from $000^{\circ}$ to $060^{\circ}$ (Fig. 2A). It is difficult to say with certainty whether this variability is caused by the sinuousity of the fault scarps or by faults of different generations. In some instances, however, the latter seems to be more probable: some northeast-southwest lineaments apparently cut short north-trending features at the northern end of the high backscattering region (Fig. 2A).

\section{GLORIA Lineament Analysis of the Area around Site 841}

Our preliminary structural interpretation of the GLORIA sonographs in the vicinity of the drillsite is made from a $\sim 4500 \mathrm{~km}^{2}$ area of the CD33 swath between $22^{\circ} 30^{\prime}$ and $23^{\circ} 40^{\prime} \mathrm{S}$. It was designed to be nondiscriminatory in terms of the lineaments that were picked so as to be as objective as possible, with the intention of simulating an automated analysis. All linear features that could be recognized on the sonographs were traced and their orientations and lengths measured; no reference was made to surface morphology.

The average trend of the contours in the area of the analysis is $029^{\circ}$, and the ship's track is $202^{\circ}\left(022^{\circ}\right)$. The lineaments picked from the GLORIA image show a marked preferred orientation, with a mean trend of $023.3^{\circ}$ and standard deviation of $11.6^{\circ}$. Although the mode 
of the data falls between $025^{\circ}$ and $030^{\circ}$ (Fig. 3A), that is, close to the strike of the slope, the fact that the mean trend is almost exactly track parallel leads us to suspect that the lineament distribution is indeed influenced by artefacts on the sonographs. As discussed above, smearing of slightly oblique targets to make them appear track-parallel is an unavoidable consequence of sidescan imaging systems, and we have evidence from other parts of the same GLORIA mosaic (e.g., Fig. $2 \mathrm{~A}$, at $24^{\circ} 30^{\prime} \mathrm{S}$; see above) that track-parallel elongation of pointsource targets has been significant.

The Mason et al. (1992) deblurring algorithms are designed to increase along-track resolution at far range and therefore should reduce the elongation effects; however, we found no difference in the distribution of lineaments between the normally processed and the deblurred mosaics. We therefore attempted to assess and account for the bias caused by the far-range smearing by dividing the data into nearand far-range subsets, based upon their distance from the vehicle track. Figures $3 \mathrm{~B}$ and $3 \mathrm{C}$ show that the two subsets have similar means (far range $=022.4^{\circ}$; near range $=024.5^{\circ}$ ) and almost identical angular standard deviations (far range standard deviation $=11.9^{\circ}$; near range $=12.0^{\circ}$ ). If the true lineament distribution is assumed to be identical across the whole swath, then the difference between the near- and far-range data (Figs. 3B-3C) can be ascribed to the far-range smearing effects. We therefore filtered the far range lineaments by eliminating all features less than $1.5 \mathrm{~km}$ in length, i.e. with a cut-off slightly greater than the calculated elongation of a point source (Fig. 3D). However, although the filtering reduces the number of eligible lineaments, the mean trend is identical (at $022.4^{\circ}$ ) and the variance is reduced even further $\left(\right.$ standard deviation $\left.=11.2^{\circ}\right) ; \chi^{2}$ tests show that there is still a statistically significant difference between the near-range (Fig. 3B) and filtered far-range data (Fig. 3D).

From the above arguments, and because the vehicle track is so close to the "expected" lineament trend, it is clear that we cannot be confident that the "quantitative" lineament picking approach we have taken is able to account fully for the image artefacts, whatever filters are applied. We therefore reverted to a more traditional, qualitative approach, making a second lineament analysis that instead focussed upon the longer lineaments, and including those features oblique to the ship's track that are defined by en echelon track-parallel targets. The short, discontinuous track-parallel lineaments from the mottled terrain on the inner slopes (Fig. 2A) that we infer to be artefacts were deliberately excluded. This somewhat interpretative approach to lineament identification is more conventional, but relies heavily upon the experience of the sonograph interpreter, and lends itself much less readily to automation.

Because of the much smaller number of lineaments that were adjudged to represent real features we found it necessary to widen the area of analysis to the $\sim 13,000 \mathrm{~km}^{2}$ area of the complete mosaic shown in Figure $2 \mathrm{~A}$ (minus the $1000 \mathrm{~km}^{2}$ area of the outer trench slope to the east of the trench axis). The distribution of lineaments (Fig. 4) is much broader than before, with a mean trend of $019.9^{\circ}$ and standard deviation of $17.7^{\circ}$. Although we are now considering sonographs with both north-northeast-south-southwest and north-south tracks (and, hence, that we may have also introduced north-trending artefacts), we have greater confidence that the increased variance is not simply a consequence of GLORIA course changes and track-parallel data smearing effects, since most of the lineaments are long (average length $=12.8$ $\mathrm{km}$, standard deviation $=5.7 \mathrm{~km}$ ) and/or oblique to the ship's track. The area of this second investigation now spans the broad change of trench trend from north to north-northeast that occurs to the north of the Louisville Ridge collision zone (see "Introduction" section above, and Fig. 1A), and the distribution of lineaments need not, therefore, be identical to that from the area chosen for the initial analysis.

\section{Structural Information from Site 841 Boreholes}

In addition to GLORIA or other sidescan sonar surveys, investigation of the structure of the inner slope of the Tonga Trench is possible with reference to subsurface data from the Site 841 boreholes. Structural data from boreholes can be acquired in two principal ways: either from features preserved within the recovered core itself, or from those detected by downhole imaging logging tools. The Formation MicroScanner (FMS) measures fine-scale variations in the resistivity of the borehole wall. The resistivity data are processed to form detailed ( $\leq 5-\mathrm{mm}$ vertical resolution) images of the borehole (Ekstrom et al., 1987), with features such as bedding and fractures typically being very well resolved. The tools carry three-axis magnetometers, and thus allow orientation of the images relative to true coordinates. This offers a significant advantage over studies based upon core data alone, which are handicapped by the preferential obliteration (and hence nonrecovery) of faulted rocks during drilling and, more seriously, that the recovered core pieces are not oriented with respect to azimuth. Features in cores cannot easily be related to geographical coordinates, and it is consequently difficult to appreciate their overall tectonic significance. Although magnetometer-bearing downhole tools that scribe orientation marks onto the core as it enters the core barrel do exist, such devices are only now being introduced by ODP and were not available for use at Site 841 .

MacLeod et al. (this volume), however, have demonstrated that it is possible to use the FMS records not only to image structures directly, but also to reorient pieces of core to geographical coordinates. This is achieved simply by matching distinctive features in the core (e.g., inclined bedding) to their equivalent borehole images from the same interval. Reorienting core in this way has the significant advantage of allowing kinematic information from the core to be assessed in its spatial context.

MacLeod (this volume) has made a systematic correlation of sedimentary bedding orientations between core and logs from Site 841 , in so doing reorienting 137 faults and veins that were observed in and measured from the same core pieces, but which were too small to be recognized on the FMS records. These structures, together with the 200 fracture planes measured from the FMS images, have allowed a detailed assessment to be made of the subsurface structure of the Tonga forearc at Site 841 (see MacLeod, this volume), and provide an entirely independent data set for comparison with the GLORIA lineament interpretations discussed above.

Faults measured directly from the FMS images from Site 841 show a preferred trench-parallel trend, with a mean strike of $013.3^{\circ}$ and standard deviation of $35.3^{\circ}$ (Fig. 5A). Most dip steeply eastward, toward the trench axis (MacLeod, this volume). The 137 microfaults measured from the core and reoriented using the FMS show a very similar trend overall (mean strike $=012.6^{\circ}$, standard deviation $=$ $36.9^{\circ}$; Fig. 5B). We were able to obtain kinematic information for 127 of these microfaults, and subdivide the data into normal $(N=98)$ and reverse $(N=29)$ structures (Figs. $5 C-5 \mathrm{D})$. Although very similar in their strikes to the faults imaged directly from the FMS (mean strike $=014.3^{\circ}$, standard deviation $=35.7^{\circ}$ ), most of the normal microfaults have near vertical or steep westward dips, in contrast to the eastward dips of the major structures; consequently, they have been interpreted by MacLeod (this volume) as antithetic to the larger, eastwarddipping normal faults. The reverse faults are relatively few in number, and have slightly more northerly strikes (mean $=007.9^{\circ}$, standard deviation $=35.0^{\circ}$ ) than the normal faults.

Two major fault zones were recognized at Site 841, at depths of 450 and $605 \mathrm{~m}$ below seafloor (mbsf) (Parson, Hawkins, Allan, et al., 1992). The upper fault zone omits much of the middle Miocene succession and is inferred to have a normal displacement in the order of hundreds of meters (MacLeod, this volume). The lower fault zone separates middle Eocene sediments from a rhyolitic arc complex of unknown age; this fault zone, too, is presumed to have a normal sense of displacement, although its magnitude cannot be constrained. The FMS data show the upper fault zone to be north-northeast striking (i.e., trench parallel), and dipping steeply eastward; and the lower fault zone to be striking northeastward and dipping moderately toward the southeast (MacLeod, this volume). 


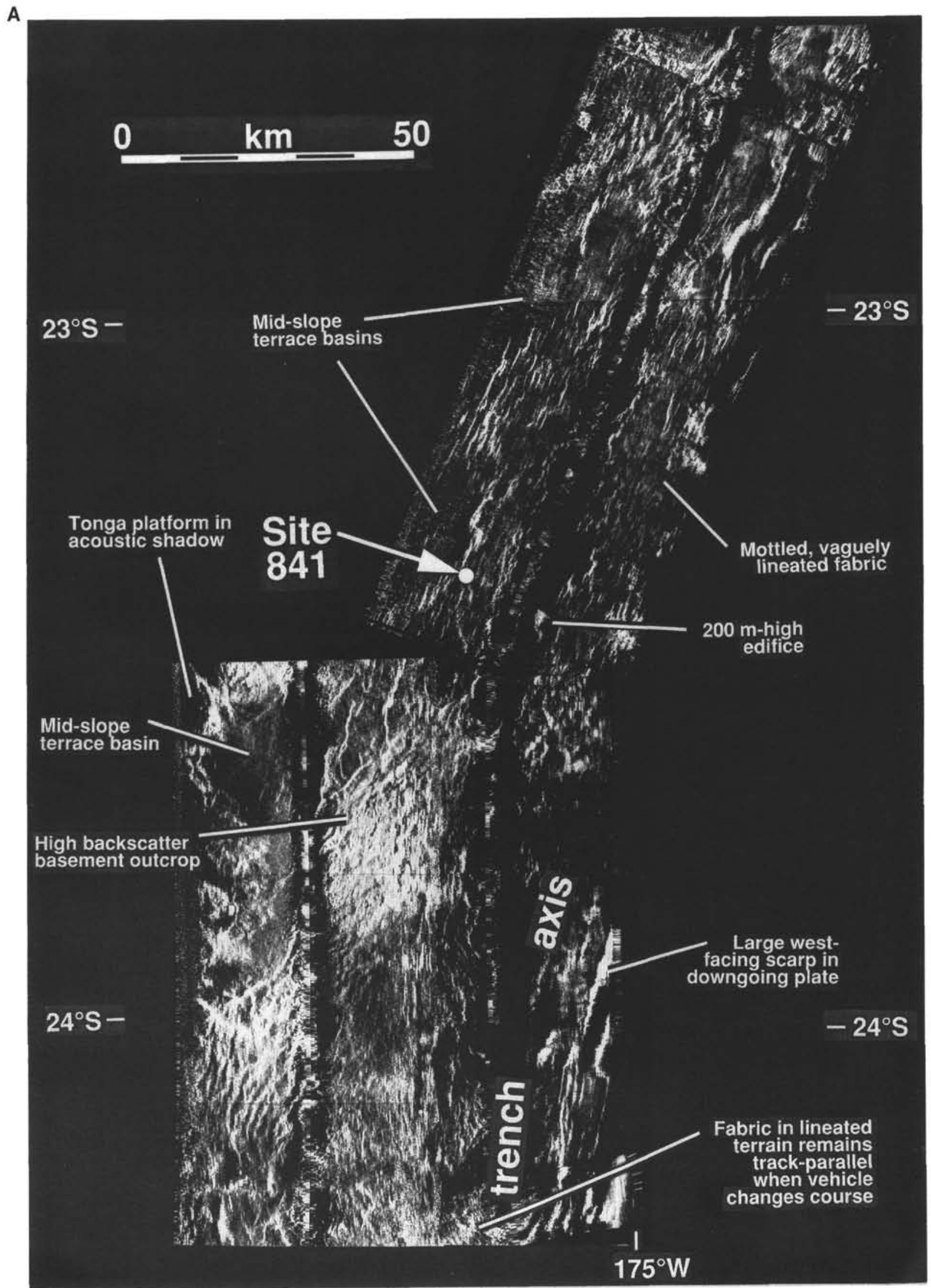

Figure 2. See caption on facing page 
B

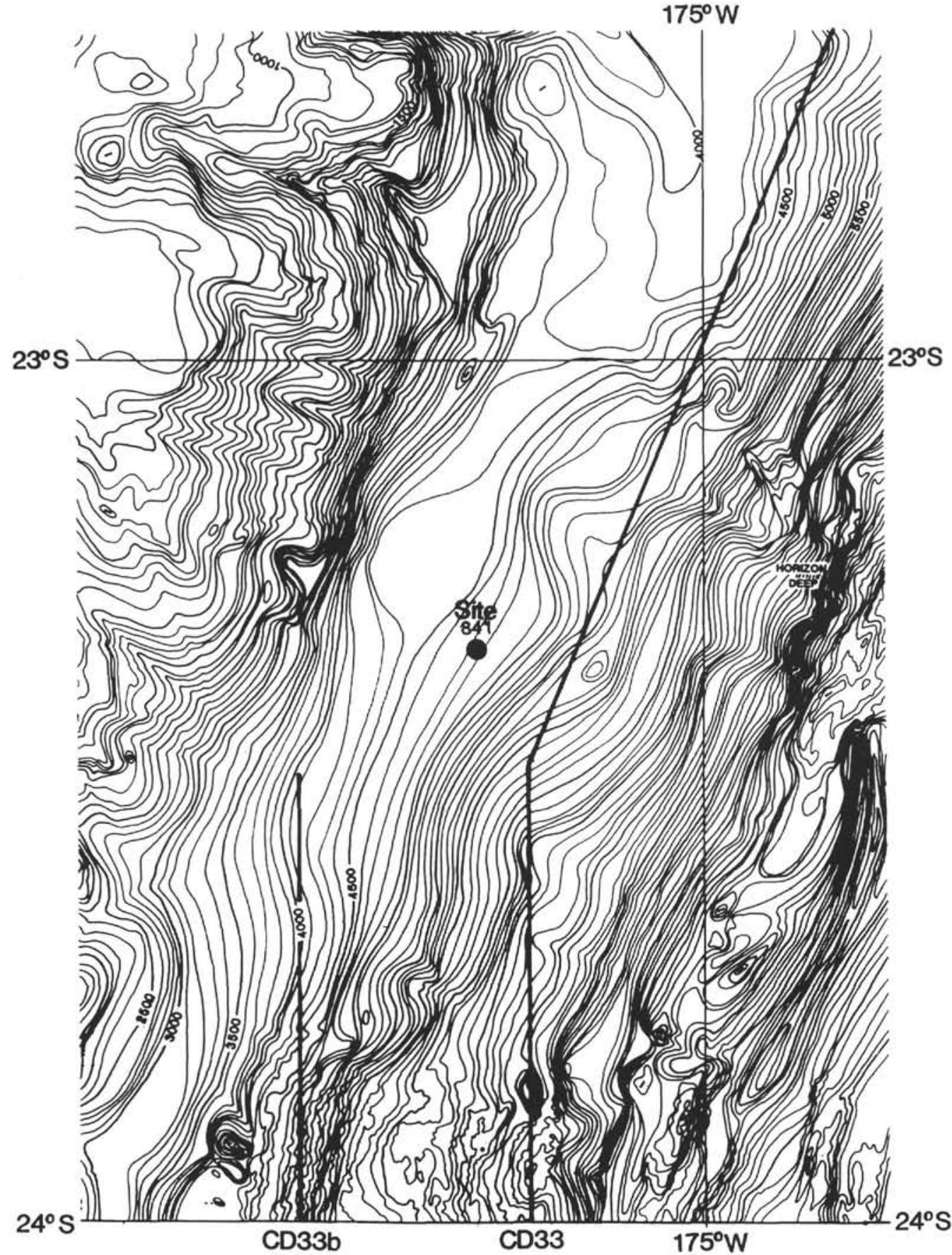

Figure 2. A. GLORIA mosaic of the area around Site 841. The second lineament analysis was conducted on this portion of Figure 1B. Note the lineated, mottled texture of the lower trench slopes discussed in the text; also the reticulate pattern in the high-backscattering area to the south-southwest of the drill site, which appears to show north-trending lineaments truncated by north-northeast-trending ones. In general, lineaments to the south of this latitude $\left(\sim 23^{\circ} 30^{\prime} \mathrm{S}\right)$ have an overall north-south trend; to the north, a north-northeast-south-southwest trend predominates. B. Bathymetry, from Parson et al. (1992), of most of the area of the GLORIA imagery shown in Figure 2A. The ships' tracks from Cruises CD33 and $\mathrm{CD} 33 \mathrm{~B}$ are marked as bold lines. Bathymetric contours are in meters.

\section{DISCUSSION}

In the preceding sections of this paper, we have attempted to assess the distribution of fault orientations on the inner slope of the Tonga Trench, both from the surface expressions of faults, as recorded by the GLORIA sidescan sonographs, and from faults intersected subsurface during drilling at Site 841 . It is obvious from the above that the geological interpretation of the GLORIA records from the Tonga Trench has not been straightforward: close scrutiny of the mosaics shows many of the shorter, discontinuous linear features common on the sonographs to be artefacts. Many of the artefacts result from along-track elongation of high-backscattering, point-source targets of a size comparable to the far-range resolution of GLORIA. These targets are probably kilometer-sized or less slump blocks and/or irreg- 
A

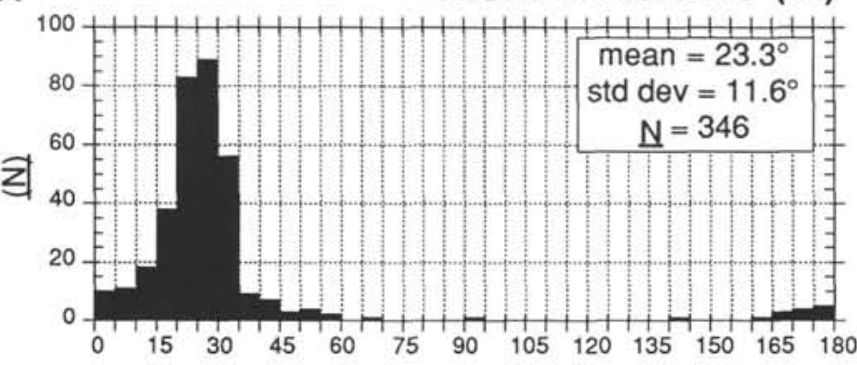

B

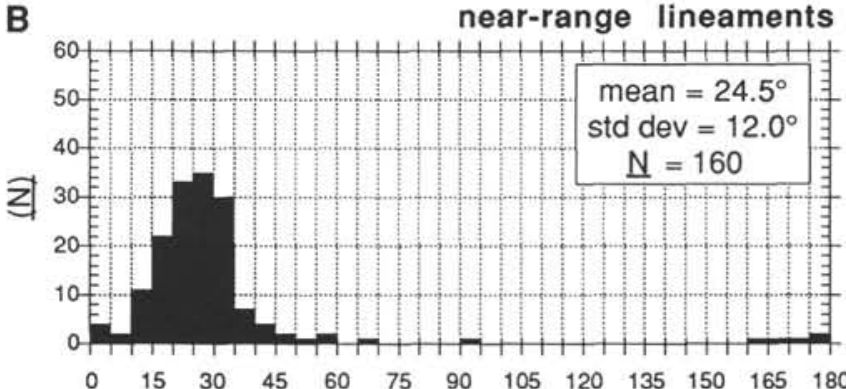

C

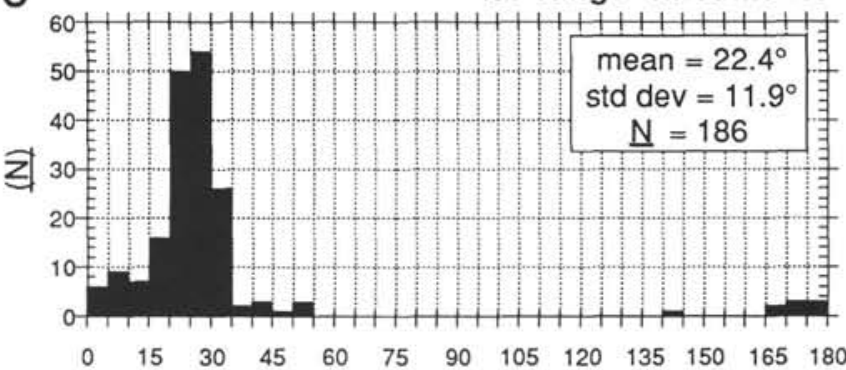

D

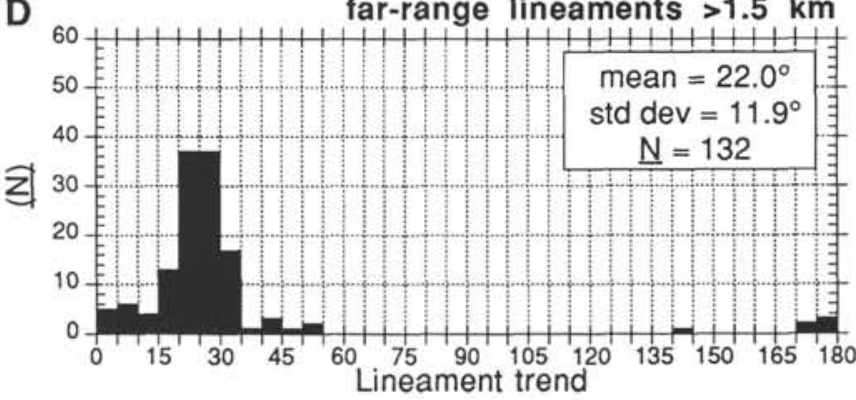

Figure 3. Frequency histograms of lineations obtained from the nondiscriminatory "objective" lineament analysis. The lineament trend is plotted on the $x$-axis. The ship's heading is $022^{\circ}$ in each case. A. Undifferentiated data. Note the very strong ship's track-parallel distribution of the data. A consequence of the geometry of GLORIA's acoustic emission pulse is a very elongate "footprint" at far range, such that point-source targets are stretched into targets up to $1.2 \mathrm{~km}$ long parallel to the vehicle track. In an attempt to assess the possible vehicle-parallel bias, the data were subdivided into lineaments either close to or far from the ship's track (Figs. 3B and 3C, respectively). The far-range data are slightly more tightly clustered than the near-range, and the maximum lineament azimuth differs slightly. The difference between the two data sets attributable to the point-source smearing effect. D. Filtering out lineaments $<1.5 \mathrm{~km}$ long from the far-range data does not change either the mean or the variance of the distribution.

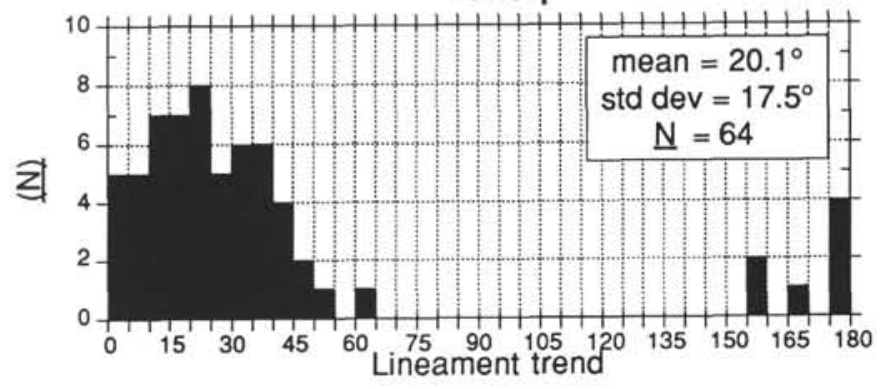

Figure 4. Distribution of the larger lineaments recognized from the manual interpretation of the GLORIA mosaic shown in Figure $2 \mathrm{~A}$. A cumulative length vs. orientation histogram for the same data shows a very similar distribution.

ular basement outcrops that we think characterize much of the lowermost slopes on the inner trench wall. The poor quality of the Tonga Trench GLORIA data is probably a consequence of the extreme across-track slopes and exceptional water depths encountered, and because the vehicle tracks were parallel or near parallel to the trend of the principal tectonic features.

Automated, nondiscriminatory lineament recognition techniques are affected seriously by the track-parallel artefacts, even after application of the various filtering procedures that should theoretically be able to eliminate them. We have therefore been forced to adopt a more qualitative approach to the analysis of the GLORIA mosaics, identifying manually lineaments that are too large and/or oblique to the vehicle track to be artefacts. By so doing we have recognized 64 highbackscattering, linear features that we are confident represent fault scarps. Comparison of the sonographs with bathymetric and seismic reflection data supports the interpretation, showing that many of the lineaments coincide with east-facing scarps up to $100 \mathrm{~m}$ high and high-angle discontinuities on the seismic records.

Further support is offered, we think, from a comparison of the GLORIA and Site 841 structural data. Despite the fact that the two data sets were not actually measured from the same seafloor features (and no a priori reason, therefore, that the distributions should be identical), and are derived by entirely independent means, the distribution of orientations is remarkably similar (Figs. 4-5). The GLORIA data show that the predominant fault trend on the inner trench slope is between $000^{\circ}$ and $030^{\circ}$ ( $57.8 \%$ of the lineaments), and suggest that within this spread of orientations there may possibly be two populations of faults (at $23^{\circ} 30^{\prime}$ to $24^{\circ} \mathrm{S}$ : an older north-striking generation cut by a younger north-northeast-trending set). The Site 841 subsurface data show that the faults are mostly of normal displacement, throwing down eastward toward the axis of the Tonga Trench. The largest of the faults intersected at Site 841 is estimated to have had a total normal displacement in the order of hundreds of meters (comparable in size to the largest of the scarps recognized on the inner trench slope). The strikes of the faults from Site 841 show slightly greater scatter than the GLORIA faults, and a bias toward more northerly directions $(29.5 \%$ of faults trend between $350^{\circ}$ and $010^{\circ}$, compared with $21.9 \%$ of the GLORIA lineaments). There is a suggestion of bimodality in the distribution of faults from Site 841 (Fig. 5); however, no obvious cross-cutting relationships were observed either in the cores or on the FMS images. The greater number of northerly striking structures from Site 841 may be caused by local effects, the drill site being located on a small north-trending topographic arch (Parson, Hawkins, Allan, et al., 1992). Alternatively, the higher number of north-striking faults may be related to the slight change in the regional trend of the inner wall of the Tonga Trench that occurs at approximately $23^{\circ} 30^{\prime} \mathrm{S}$, from $000^{\circ}$ to the south of this latitude to $030^{\circ}$ to the north (Fig. 1A). The north-trending region is part of a $250-\mathrm{km}$-long embayment in the trench wall created by collision of the Louisville Seamount Chain with the trench and its subsequent subduction. It is possible that the distribution of fault orientations we have obtained from the area surrounding the drill site is documenting a 

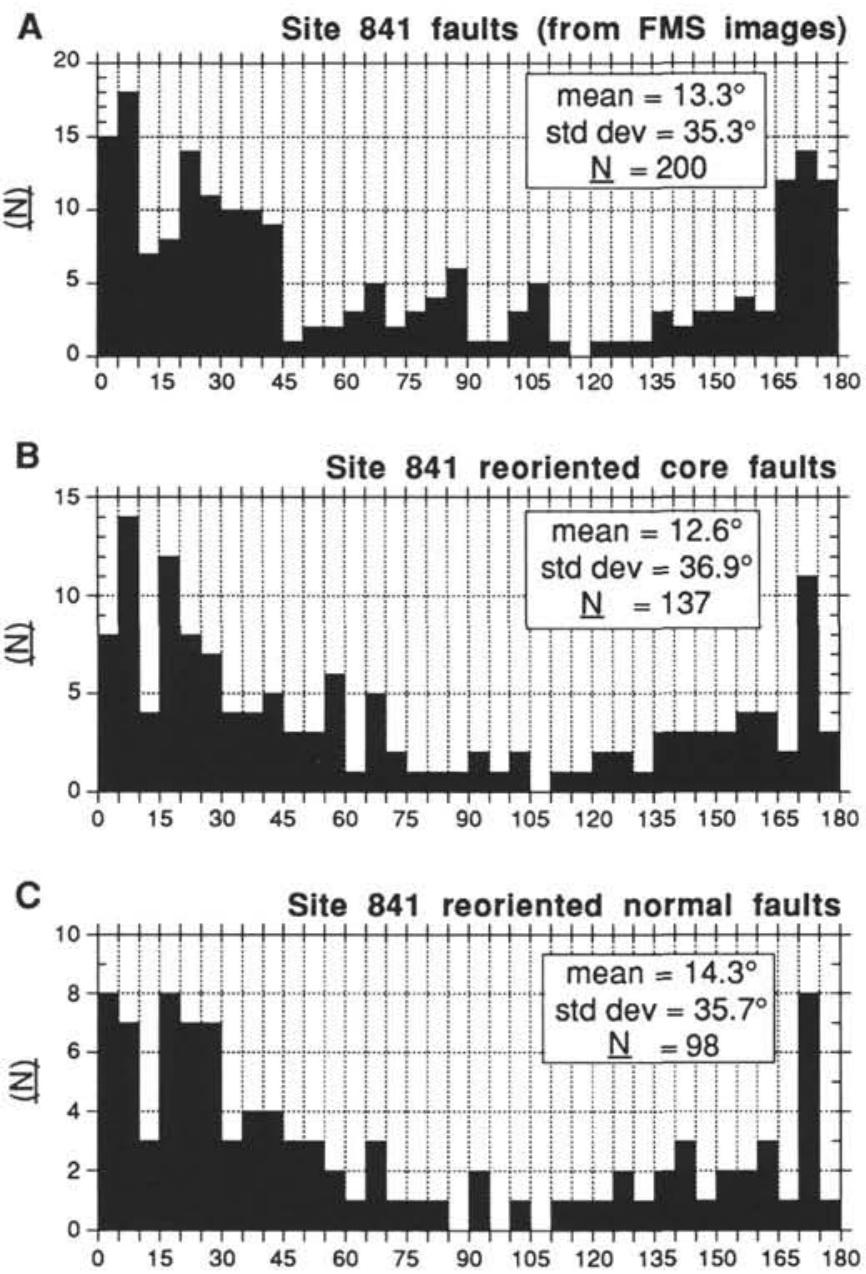

D

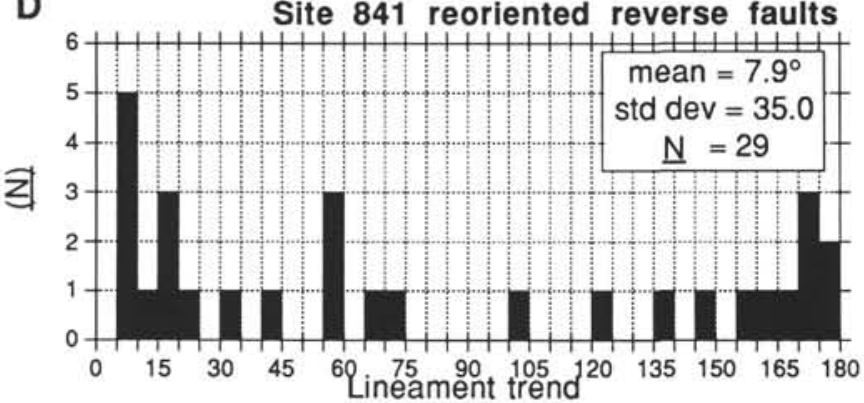

Figure 5. Distribution of faults at Site 841. A. Histogram of faults and fractures measured directly from FMS images from Hole 841C. B. Histogram of faults (undifferentiated) measured from the Site 841 cores and reoriented following the procedure described by MacLeod et al. (this volume). C-D. Reoriented core data from Figure 5B subdivided into normal and reverse faults, respectively. See text for discussion.

reestablishment of the regional $020^{\circ}$ trend (perpendicular to the plate convergence direction) at the expense of the northerly trend created by collision of the Louisville Ridge with the trench. Fault data from Site 841 indicate that both the north- and north-northeast-striking fault trends are dominated by eastward- to east-southeast-throwing normal structures, with abundant evidence for trenchward-directed failure of the whole inner slope by gravity-driven processes (MacLeod, this volume). The GLORIA sonar images confirm that much of this embayed region of the inner trench slope is characterized by large-scale mass wasting.

\section{CONCLUSIONS}

GLORIA sidescan sonographs of the inner wall of the Tonga Trench reveal a variety of acoustic facies that we think document mid-slope terrace basins, rugged basement outcrop, and (particularly on the lowermost slopes) large areas of mass-wasted debris. Long (average $13 \mathrm{~km}$ ), high-backscattering lineaments correlating with bathymetric offsets and/or seismic discontinuities are interpreted as fault scarps; however, a much larger number of shorter $(\sim 1-2 \mathrm{~km}$ scale), discontinuous lineaments visible on many of the GLORIA sonographs are thought to be ship's track-parallel image artefacts.

The distribution of faults on the inner wall of the trench has also been investigated by the analysis of subsurface structures from Site 841 borehole cores and downhole electrical images. The downhole and sonar data are entirely independent of each other, and offer a rare opportunity to assess the strengths and weaknesses of the two different methods of structural interpretation. Once the image artefacts on the GLORIA sonographs have been accounted for, the distributions of faults from the two sources compare closely. The faults have an overall trench-parallel trend, are of normal displacement, with the larger structures downthrowing eastward into the axis of the trench. The GLORIA and Site 841 data both show hints of bimodality in the fault distribution, with distinct $000^{\circ}$ and $030^{\circ}$ maxima. Cross-cutting lineaments on the GLORIA records suggest that faults of the latter trend may postdate those of the former. This may be related to the slight change in the regional trend of the inner wall of the Tonga Trench that occurs at approximately $23^{\circ} 30^{\prime} \mathrm{S}$, from $000^{\circ}$ to the south of this latitude to $\sim 030^{\circ}$ to the north. It is possible that the distribution of fault orientations from the area surrounding the drill site documents the reestablishment of the regional north-northeast trend at the expense of the northerly trend created by impaction of the Louisville Ridge into the trench.

\section{ACKNOWLEDGMENTS}

We are indebted to Lindsay Parson for his encouragement and invaluable advice at all stages of preparation of this paper, and would like to thank Colin Jacobs for much help and useful discussion. The paper has benefited greatly from the attentions of two anonymous reviewers, and from Graham Westbrook, Doug Masson, and Bram Murton. Tim LeBas and Ian Mitchell are thanked for their efforts with the GLORIA processing. We are grateful to Robin Falconer and the Defence Scientific Establishment of the New Zealand Ministry of Defence for permission to use the Cruise CD33B data. This work was supported by the Natural Environment Research Council in the form of a research grant to L.M. Parson/C.J. MacLeod and a research studentship to A.M. Lothian.

\section{REFERENCES $*$}

Austin, J.A., Taylor, F.W., and Cagle, C.D., 1989. Seismic stratigraphy of the Central Tonga Ridge. Mar. Pet. Geol., 6:71-92.

Ballance, P.F., Scholl, D.W., Vallier, T.L., Stevenson, A.J., Ryan, H., and Herzer, R.H., 1989. Subduction of a Late Cretaceous seamount of the Louisville Ridge at the Tonga Trench: a model of normal and accelerated tectonic erosion. Tectonics, 8:953-962.

Bloomer, S.H., and Fisher, R.L., 1987. Petrology and geochemistry of igneous rocks from the Tonga Trench-a non-accreting plate boundary. J. Geol., 95:469-495.

Chavez, P.S., 1986. Processing techniques for digital sonar images from GLORIA. Photogramm. Eng. Remote Sens., 52:1133-1145.

Clague, D.A., and Jarrard, R.D., 1973. Tertiary plate motion deduced from the Hawaiian-Emperor Seamount Chain. Geol. Soc. Am. Bull., 84:1135-1154.

\footnotetext{
-Abbreviations for names of organizations and publication titles in ODP reference lists follow the style given in Chemical Abstracts Service Source Index (published by American Chemical Society).
} 
Dupont, J., 1982. Morphologie et structures superficielles de l'arc insulaire des Tonga-Kermadec. In Contribution à l'étude Geodynamique du SudOuest Pacifique. Trav. Doc. l'ORSTOM, 147:263-282.

Dupont, J., and Herzer, R.H., 1985. Effect of subduction of the Louisville Ridge on the structure and morphology of the Tonga Arc. In Scholl, D.W., and Vallier, T.L. (Eds.), Geology and Offshore Resources of Pacific Island Arcs-Tonga Region. Circum-Pac. Counc. Energy Miner. Resour., Earth Sci. Ser., 2:323-332.

Ekstrom, M.P., Dahan, C., Chen, M.-Y., Lloyd, P., and Rossi, D.J., 1987. Formation imaging with microelectrical scanning arrays. Log Analyst, 28:294-306.

Fischer, K.M., Creager, K.C., and Jordan, T.H., 1991. Mapping the Tonga slab. J. Geophys. Res., 96:14403-14427.

Fisher, R.L., and Engel, C.G., 1969. Ultramafic and basaltic rocks dredged from the nearshore flank of the Tonga Trench. Geol. Soc. Am. Bull., 80:1373-1378.

Gnibidenko, H.S., Anosov, G.I., Argentov, V.V., and Pushkin, I.K., 1985. Tectonics of the Tonga-Kermedec Trench and Ozbourn Seamount junction area. Tectonophysics, 112:357-383.

Herzer, R.H., and Exon, N.F., 1985. Structure and basin analysis of the southern Tonga forearc. In Scholl, D.W., and Vallier, T.L. (Eds.), Geology and Offshore Resources of Pacific Island Arcs-Tonga Region. CircumPac. Counc. Energy Miner. Resour., Earth Sci. Ser., 2:55-73.

Hilde, T.W.C., 1983. Sediment subduction versus accretion around the Pacific. Tectonophysics, 99:381-397.

Isacks, B.L., and Barazangi, M., 1977. Geometry of Benioff zones: lateral segmentation and downwards bending of the subducted lithosphere. In Talwani, M., and Pitman, W.C., III (Eds.), Island Arcs, Deep Sea Trenches, and Back Arc Basins. Am. Geophys. Union, Maurice Ewing Ser., 1:94-114.

Isacks, B.L., Sykes, L.R., and Oliver, J., 1969. Focal mechanisms of deep and shallow earthquakes in the Tonga-Kermadec region and the tectonics of island arcs. Geol. Soc. Am. Bull., 80:1443-1470.

Johnson, H.P., and Helferty, M., 1990. The geological interpretation of sidescan sonar. Rev. Geophys., 28:357-380.

Kayen, R.E., Torresan, M.E., Dadisman, S.V., Clague, D.A., Drake, D.E., Gutmacher, C.E., Hampton, M.A., Marlow, M.S., Moore, J.G., Normark, W.R., Pickthorn, L.G., Shor, S., Denlinger, R.P., Holcomb, R.T., Holmes, M., Lipman, P.W., Belderson, R.H., Jacobs, C.L., Searle, R.C., Wilson, J.B., and Rothwell, R.G., 1990. GLORIA side-scan sonar imagery of the Hawaiian Islands Exclusive Economic Zone. Eos, 71:1580.

Laughton, A.S., 1981. The first decade of GLORIA. J. Geophys. Res., 86:11511-11534.

Lonsdale, P., 1986. A multibeam reconnaissance of the Tonga Trench axis and its intersection with Louisville Guyot Chain. Mar. Geophys. Res., 8:295327.

, 1988. Geography and history of the Louisville hotspot chain in the Southwest Pacific. J. Geophys. Res., 93:3078-3104.

Mason, D.C., LeBas, T.P., Sewell, I., and Angelikaki, C., 1992. Deblurring of GLORIA side-scan sonar images. Mar. Geophys. Res., 14:125-136.

Masson, D.G., 1991. Fault patterns at outer trench walls. Mar. Geophys. Res., 13:209-225.

Masson, D.G., Parson, L.M., Milsom, J., Nichols, G., Sikumbang, N., Dwiyanto, B., and Kallagher, H., 1990. Subduction of seamounts at the Java Trench: a view with long-range sidescan sonar. Tectonophysics, 185:5165.
Mayer, W., Jacobs, C., and Parson, L.M., 1990. Tectonic and sedimentary processes in the Tonga-Kermadec Trench and adjacent terranes: a GLORIA long-range sidescan sonar survey. Gondwana: Terranes and Resources. Geol. Soc. Austral. Abstr. No. 25, Tenth Austral. Geol. Conv., Hobart.

Parson, L., Hawkins, J., Allan, J., et al., 1992. Proc. ODP, Init. Repts., 135: College Station, TX (Ocean Drilling Program).

Parson, L.M., et al., 1989. Charles Darwin Cruise 33/88, 5 May-1 June 1988. Geophysical surveying and geological sampling in the Lau back-arc basin, SW Pacific Ocean. Inst. Oceanogr. Sci. Deacon Lab. Cruise Rep., 206.

Parson, L.M., Evans, A.J., and Hunter, P.M., 1992. Bathymetric Charts of the Lau Basin at 1:375,000. Inst. Oceanogr. Sci. Deacon Lab. Rep., Chart 7.

Pelletier, B., and Louat, R., 1989. Seismotectonics and present day relative plate motions in the Tonga-Lau and Kermadec-Havre region. Tectonophysics, 165:237-250.

Pontoise, B., Pelletier, B., Aubouin, J., Baudry, N., Blanchet, R., Butscher, J., Chotin, P., Diament, M., Dupont, M., Eissen, J., Ferrière, J., Herzer, R., Lapouille, A., Louat, R., d'Ozouville, L., Soakai, S., and Stevenson, A., 1986. Subduction of the Louisville Ridge along the Tonga Trench: preliminary results of SEAPSO campaign (Leg V). C. R. Acad. Sci. Ser. 2, 10:911-918

Scholl, D.W., Vallier, T.L., and Packham, G.H., 1985. Framework geology and resource potential of the southern Tonga platform and adjacent terranes-a synthesis. In Scholl, D.W., and Vallier, T.L. (Eds.), Geology and Offshore Resources of Pacific Island Arcs-Tonga Region. Circum-Pac. Counc. Energy Miner. Resour., Earth Sci. Ser., 2:457-488.

Searle, R.C., LeBas, T.P., Mitchell, N.C., Somers, M.L., Parson, L.M., and Patriat, P., 1990. GLORIA image processing: the state of the art. Mar. Geophys. Res., 12:21-39.

Somers, M.L., Carson, R., Revie, J., Edge, R., Barrow, B., and Andrews, A., 1978. GLORIA II-an improved long range sidescan sonar. Proc. IEEE/IERE Subconference on Offshore Instrumentation, Oceanology International '78, Technical Session J. London (BPS Publ.), 16-24.

Tappin, D.R., Herzer, R.H., and Stevenson, A.J., 1992. Structure and history of an oceanic forearc - the Tonga Ridge $22^{\circ}$ to $26^{\circ}$ South. In Ballance, P.F., Herzer, R.H., and Stevenson, A.J. (Eds.), Geology and Resources of Island Arcs, Tonga-Lau-Fiji Region: Berlin (Springer-Verlag).

Vallier, T.L., O'Connor, R.M., Scholl, D.W., Stevenson, A.J., and Quinterno, P.J., 1985. Petrology of rocks dredged from the landward slope of the Tonga Trench: implications for middle Miocene volcanism and subsidence of the Tonga Ridge. In Scholl, D.W., and Vallier, T.L. (Eds.), Geology and Offshore Resources of Pacific Island Arcs-Tonga Region. Circum-Pac. Counc. Energy Miner. Resour., Earth Sci. Ser., 2:109-120.

von Huene, R., and Scholl, D.W., 1991. Observations at convergent margins concerning sediment subduction, subduction erosion, and the growth of the continental crust. Rev. Geophys., 29:279-316.

Watts, A.B., Weissel, J.K., Duncan, R.A., and Larson, R.L., 1988. Origin of the Louisville Ridge and its relationship to the Eltanin Fracture Zone. J. Geophys. Res., 93:3051-3077.

Date of initial receipt: 30 September 1992

Date of acceptance: 28 July 1993

Ms 135SR-158 